\title{
On the Integration of Logistics Activities by Shipping Lines: The Case of East-Asia ${ }^{+}$
}

\author{
Francesco Parola*, Sung-Woo Lee ${ }^{* *}$ and Claudio Ferrari***
}

\begin{abstract}
In the 1990s, following the challenges imposed by globalisation, the liner shipping industry experienced profound changes, leading major carriers to create ad-hoc logistics business-units. Nevertheless the vertical integration of shipping lines along the transport chain faced important entry barriers in various regions. This paper aims at analysing the impact of such barriers on carriers' pathways of expansion in the logistics business. It mainly focuses on the East-Asian market, as a relevant empirical case in which important institutional and socio-political obstacles are still in force. Main results disclose sui-generis paths of expansion achieved by major carriers, in contrast with linear constructs of time and space proposed by classical TNC theories. In such respect, port operations reveal to be the most critical stage of the chain. The 'sidestep' of the port phase, leading to investments in other on-shore activities (warehousing, inland terminals, etc.) as well as the
\end{abstract}

Submission Date: 5/19/2006 Acceptance Date: 6/9/2006

${ }^{*}$ Corresponding Author: Professor, University of Genoa - Department of Business Studies and Italian Centre of Excellence for Integrated Logistics (CIELI), Via Vivaldi 5, 16126 Genoa (Italy); tel. +39 010 2095071, fax +39 010 209508, E-mail: parola@economia.unige.it

${ }^{* *}$ Researcher, Korea Maritime Institute - Centre of Shipping, Port and Logistics Planning

Bangbae-dong, Seocho-gu, Seoul (Korea), tel. +82 2 21052830; fax +82 221052839

E-mail: waterfront@kmi.re.kr

${ }^{* * *}$ Professor, University of Genoa - Department of Economics and Quantitative Methods and Italian Centre of Excellence for Integrated Logistics (CIELI), Via Vivaldi 5, 16126 Genoa (Italy), tel. +39 010 2095235, fax +39010 2095511, E-mail: ferrari@economia.unige.it

${ }^{+}$Authors are grateful to Mr. Soo Won Lee, deputy director of the Ministry of Maritime Affairs and Fisheries (MOMAF) of the Republic of Korea, for his valuable support in collecting data and information about Asian logistics companies. 
implementation of aggressive financial campaigns (acquisitions and takeovers), reveal the unfaltering will of top shipping lines: the quick achievement of a successful vertical and horizontal expansion despite environmental obstacles.

Keywords: Maritime logistics, entry barriers, East-Asia, liner shipping, vertical integration, logistics network.

\section{INTRODUCTION}

Over the last two decades the liner shipping industry has experienced profound changes, leading to a restructuring both on the demand and the supply sides.

The globalization of the production systems and the consequent delocalization of plants in 'low-cost' countries led to a revolution in trade and transport patterns. The enlargement of the competitive landscape in manufacturing sectors triggered profound changes in shippers' behaviour, asking for cheaper, more integrated and affordable transport systems.

Top shipping lines, in turn, are experiencing the aggression of transnational stevedoring companies in the port sector (i.e. Hutchison Port Holdings, PSA, Dubai Ports World, etc.) and the progressive competition of major logistics providers offering 'one-stop shop' solutions (i.e. Deutsche Post, Deutsche Bahn, Panalpina, Kuehne \& Nagel, Fedex, UPS, etc.). Therefore the growing bargaining power of major players, mostly from neighbouring industries, port, freight forwarding, intermodal, deeply contributed to enhance the competition in the liner shipping market (Panayides and Cullinane, 2002).

All these factors, besides the resulting increased bargaining power of shippers, are leading shipping lines to the reorientation and the widening of their focus within the transport chain. M\&As and global alliances are on the agenda of main carriers in order to survive in this new liner business arena. Nevertheless, the deep changes currently affecting this sector are requiring much more than a simple intra-industry restructuring.

In fact, major steamship companies have decided to go beyond shipping operations in order to save costs, to find news sources of revenue and, more importantly, to increase customers' loyalty in the long term. 
Stevedoring operations and logistics focus are therefore becoming the 'keywords' for those carriers aiming at surviving in the current highly competitive market context. The academic literature became aware of the transnational nature of these changes, leading to vertical integration of carries in ports, a bit late. Although pioneering entries in the sector date back to the 1960s and the 1970s, early relevant contributions came out only a few years ago, following the momentum of the port reform process worldwide. Haralambides et al. (2002), Ferrari and Benacchio (2000) and Cariou (2001) recognised the growing importance of dedicated terminals, while Peters (2001) represented the first work facing the entry of pure stevedoring companies in the international container handling business. Later on, mainly economists (Notteboom, 2004; Midoro et al., 2005) and geographers (Slack and Frémont, 2005; Olivier, 2005) tried to achieve a deeper understanding of this phenomenon.

Since the logistics entry of carriers is an even more recent topic, there is still a lack of comprehensive studies (Section 2). In many countries, such development of shipping lines faced relevant entry barriers driving to a 'distortion' of their expansion pathways along the transport chain. Institutional and political restrictions, socioeconomic constraints are the main obstacles forcing some ship-owners to adopt suigeneris process of expansion.

This paper aims at investigating the impact of such entry barriers on carriers' pathways of expansion in the logistics business. In particular, the current ongoing economic transformations occurring in the Far East, suggest to focus our analysis to this context, as a significant empirical 'case study'. In fact, it represents a fast-growing and integrating market, but historically characterised by strong entry barriers ${ }^{1}$ (i.e. legislative, cultural, political, etc.) along the logistics chain for foreign private investors.

After an overview of the progressive vertical integration of carriers in intermodality and other inland (and logistics) operations (Section 2), the paper deals with an introductive scenario of the changing trade patterns in East-Asia ${ }^{2}$ (Section 3) and their impact on ports and logistics networks (Section 4). Particularly, in contrast

\footnotetext{
${ }^{1}$ For instance, until April 2002, due to the restrictive Chinese legislation (Regulations Concerning the Establishment of Sino-Foreign Joint Ventures), there was a $49 \%$ ceiling for foreign investors entering joint-ventures in ports.

${ }^{2}$ The term East-Asia is referred to the countries ranging from South-East Asia (Indochina) to Japan. In this paper, the terms East-Asia and Far East are used as synonyms.
} 
with mainstream TNC theories, the study of temporal and spatial paths of entry in such a close-market context reveals some un-traditional ways of penetrating the logistics chain (Section 5), both skipping some steps (i.e. the port phase) of the logical sequence of vertical integration and following aggressive forms of entry (M\&As). Section 6 discusses the major results emerging from the 'East-Asian case', highlighting the crucial role played by seaport entry barriers in affecting carriers' expansion strategies. Finally, Section 7 brings main conclusions and raises some stimulating questions for future research.

\section{VERTICAL INTEGRATION IN LINER SHIPPING: LOGISTICS ON THE AGENDA?}

A correct interpretation of the logistics entry by carriers calls for a deeper understanding of the term 'logistics', frequently used and somehow 'abused' in the mainstream literature, as well as for a proper methodology of analysis (Section 5) able to catch in depth the complexity of this phenomenon.

From an epistemological and historical viewpoint, the concept of logistics witnessed many transformations over the years, in the light of the progressive and deep evolution of the demand, requiring wider and more complex service packages. Intermodal services (see Table 1), warehousing and cargo consolidation represented the first 'value-added' services offered to shippers in the early stages of the containerisation process. The introduction of the landbridge option and the rise of US West coast ports gave momentum to the intermodal revolution and to the inland terminal concept. Sealand, Maersk and APL represented the main frontrunners in such operations. Later on some Asian players, following the example of their western competitors, began expanding their warehousing activities overseas and offering early intermodal services.

In those years many authors recorded the evolving trend of the market, but essentially from a 'macro' perspective, often forgetting to stress the impact on carriers' strategy and competitive relationships (micro viewpoint).

After the early experiences in intermodality and distribution, this embryonic concept of 'logistics' evolved, achieving a new and more 'omni-comprehensive' meaning. During the 1990 s the attention of shippers gradually turned to the overall supply chain, thus aiming at managing and optimizing its different stages. Door-to-door solutions became inadequate in satisfying customers' needs and some leading shipping 
lines began a deep organisational and strategic restructuring, in order to offer, on an international scale, a wider range of services, also comprehending (although still rarely) supply chain management and visibility. In other words, the widespread adoption of the Supply Chain Management approach by manufacturers and retailers is now forcing transportation providers to rethink their business processes to better satisfy customer needs (Carbone and Gouvernal, 2005), even providing 3PL and 4PL solutions.

Unlike the container terminal entry, the carriers' logistics entry, in its widest and modern meaning, has a very recent history (see Table 1).

Table 1. Main logistics branches of shipping lines' groups

\begin{tabular}{|c|c|c|c|c|}
\hline Carrier & $\begin{array}{l}\text { Intermodal } \\
\text { entry }\end{array}$ & \multicolumn{2}{|c|}{ Logistics branch } & $\begin{array}{l}\text { Logistics branch location in } \\
\text { the group structure }\end{array}$ \\
\hline Sealand & early-1970s & Sealand Logistics ${ }^{1}$ & $\begin{array}{l}\text { mid- } \\
1990 \mathrm{~s}\end{array}$ & $\begin{array}{c}\text { company took over by Maersk } \\
\text { in } 1999\end{array}$ \\
\hline $\begin{array}{l}\text { Maersk } \\
\text { Line }\end{array}$ & early-1980s & Maersk Logistics ${ }^{2}$ & 2000 & $\begin{array}{c}\text { company under Maersk A/S } \\
\text { control }\end{array}$ \\
\hline $\begin{array}{l}\text { APL } \\
(\mathrm{NOL})\end{array}$ & 1979 (1997) & APL Logistics $^{3}$ & 1997 & company under NOL control \\
\hline $\begin{array}{l}\text { NYK } \\
\text { Line }\end{array}$ & 1985 & NYK Logistics & 2000 & $\begin{array}{c}\text { company under NYK Line } \\
\text { control }\end{array}$ \\
\hline MOL & 1985 & MOL Logistics ${ }^{4}$ & 2001 & company under MOL control \\
\hline K-Line & 1986 & $\begin{array}{l}\text { K Line Logistics } \\
\text { Holdings }\end{array}$ & 2000 & $\begin{array}{l}\text { company under K-Line control } \\
\text { (K-Line Total Logistics brand) }\end{array}$ \\
\hline $\begin{array}{l}\text { Hyundai } \\
\text { MM. }\end{array}$ & 1990 & $\begin{array}{l}\text { Hyundai } \\
\text { Logistics }^{5}\end{array}$ & 1999 & $\begin{array}{l}\text { company controlled } \\
\text { by Hyundai MM. }\end{array}$ \\
\hline $\begin{array}{l}\text { Hanjin } \\
\text { Shipping }\end{array}$ & 1989 & Hanjin Logistics & 2001 & $\begin{array}{l}\text { company (overseas operations } \\
\text { only }^{6} \text { ) controlled by Hanjin Ship. }\end{array}$ \\
\hline Coscon & mid-1990s & Cosco Logistics & 2002 & $\begin{array}{l}\text { company jointly controlled by } \\
\text { Cosco Group and Cosco Pacific }\end{array}$ \\
\hline OOCL & $1990 \mathrm{~s}$ & OOCL Logistics $^{7}$ & 1999 & company under OOCL control \\
\hline
\end{tabular}

Notes: (1) formerly Buyers Consolidators (took over by Sealand's parent company in 1993)

(2) formerly Mercantile (established in 1977)

(3) AP Intermodal was established in 1985; the NOL Group entered in intermodal and logistics activities only after the takeover on APL in 1997

(4) formerly M.O. Air System Inc. (established in 1989)

(5) formerly Asia Merchant Shipping Corporation (1988) and Hyundai Logistics Corporation (1993) 
(6) domestic logistics operations are managed by Hanjin Corporation (independent from Hanjin Shipping)

(7) formerly Cargo System, the group's international freight consolidation unit. OOCL China Domestic Ltd. (since 1998) is the logistics company for China (under OOCL control).

Sources: our elaboration from Containerisation International Yearbook (various issues) and corporate interviews.

Some of the pioneering carriers in the port industry showed the way in the logistics market as well. After early experiences (late-1970s) in cargo consolidation (i.e. Mercantile for Maersk in Hong Kong, Singapore and Taiwan) and intermodal services (in the US in the 1980s), they decided to increase their range of services creating local logistics companies in some key countries and, more recently, to establish ad-hoc business units.

The above general trend, calling for the establishment of competing vertical chains, was followed up in different ways by top carriers.

The world leader in liner shipping, Maersk Line, enlarged its involvement in logistics thanks to an aggressive takeover strategy: on Sealand Logistics (1999) and P\&O Nedlloyd Logistics (2005). The Singaporean NOL, currently one of the biggest players in logistics, entered the business quite late. The takeover on APL in 1997 represented an opportunity to get into the logistic and the stevedoring markets, achieving through this aggressive financial operation a worldwide presence in both industries. Among the other Asian carriers, the three major Japanese shipping lines show the biggest background in this field, in the light of their operations (through local subsidiaries) mainly in the Far East and in the US.

On the contrary, some leading independent carriers, such as MSC, CMA-CGM and Evergreen decided to neglect intermodal and logistic activities for a long time. Essentially focused on the port-to-port business (a sort of 'low-cost' philosophy), only recently their approach has slightly changed, giving more attention to those customers' needs beyond the 'port boundaries'. The establishment of CMA-CGM Logistics seems to go in such direction. Anyway the gap with the other top carriers still remains deep and substantial.

Over the years, the above strategies pursued by leading carriers also brought deep organisational transformations. Going upstream along the transport chain and widening the geographical focus of their operations, shipping lines needed to restructure their organisation. In fact, they progressively concentrated and coordinated country-based logistics operations under domestic-based headquarters (see Section 5). 
Finally, in the late-1990s, the strategic power on logistics activities was 'spun-off' from the carrier to the logistics business units. Anyway, in most cases, local logistics companies are still financially controlled by the parent company (i.e. NYK Line, Mitsui O.S.K. Lines, etc.) and not directly by the logistics branch, that essentially keeps strategic tasks of coordination and planning.

Therefore, branches such as MOL Logistics and Maersk Logistics, now represent an internal division within the carrier's group, aiming at supervising and rationalizing all the activities carrier out by local subsidiaries. The established intra-group 'relationship of power' between the carrier and its logistics branch leads in most cases the shipping line to directly control the logistics branch (except for APL and APL Logistics, both under NOL control). Afterwards, although carrier's top management is used to present liner and logistics divisions as completely independent business units, the logistics branch still is, de facto, a strategic tool for shipping lines to improve customer's fidelity, turnover and operational margin.

Despite the above important changes in the logistics industry, the international literature still gives only partial and fragmented contributions. Early research came from Heaver (1994; 1996; 2002), Slack et al. (1996), Notteboom and Winkelmans (2001), De Souza Junior et al. (2003), Panayides and So (2005), and Robinson (2002, 2006). Recently, a more focused work on shipping lines and their logistics branches has been written by McCalla et al. (2004). Although recognising the growing role of logistics for shipping lines, they neglected to face strategic and organisational implications of this phenomenon from a firm viewpoint.

On the contrary this paper, focusing on the current trend in the Far East market (Sections 3-4), aims at locating the firm at the 'core' of the analysis (Sections 5-6-7), thus recognizing its leading role within this evolving logistics framework. 


\section{THE 'EAST-ASIAN' MARKET: ECONOMIC AND ENVIRONMENTAL BACKGROUND}

Following the collapse of the Eastern bloc countries, the shifting of China towards market economies together with the emergence of the several regional economic blocks, such as NAFTA, ASEAN and EU, globalization has become a popular trend in the world over the past few decades.

One of the major drivers of this trend is China's opening of its industries through Economic Reforms, beginning in 1978. An increasing number of transnational corporations (TNCs) is advancing into Asia, and many of them have China as their prime focus.

This trend has strongly affected the growth of the Far East economy including the Chinese. As a result, the trade among three countries, such as China, South Korea and Japan, has rapidly increased and all three have become a region of economic integration (Lee, 2005). East-Asia has registered the most rapid expansion over the past 10 years, and the amount of exports of merchandise arose from 614 billion US dollars (a 14.2\% share of world) in 1994 to 1,413 billion US dollars (a 15.4\% share of world) in 2004, as shown in Table 2.

Table 2. The current situation of the amount of export and import in Asia (2004)

\begin{tabular}{c|c|c|c|c|c|c}
\hline \multirow{2}{*}{ Category } & \multicolumn{2}{|c|}{ The amount of export } & \multicolumn{2}{c|}{ The amount of import } & \multicolumn{2}{c}{ Total } \\
\cline { 2 - 7 } & Billion US\$ & $\%$ & Billion US\$ & $\%$ & Billion US\$ & $\%$ \\
\hline \hline World & 9,153 & 100.0 & 9,495 & 100.0 & 18,648 & 100.0 \\
Asia & 2,388 & 26.1 & 2,224 & 23.4 & 4,612 & 24.7 \\
China & 593 & 6.5 & 561 & 5.9 & 1,115 & 6.2 \\
South Korea & 254 & 2.8 & 225 & 2.4 & 478 & 2.6 \\
Japan & 566 & 6.2 & 455 & 4.8 & 1,020 & 5.5 \\
Rest of Asia & 976 & 10.7 & 984 & 10.4 & 1,959 & 10.5 \\
\hline
\end{tabular}

Sources: WTO, International Trade Statistics 2005.

Figure 1 shows the change of trading share per major region in the world. The trading share in Far East has increased from 30\% in 1995 to $46.2 \%$ in 2003. The relationship between NAFTA, EU and Far East in 2003 is much stronger than in 1995. The figure reflects the progressive economic integration of the world thanks to free 
trade resulting from globalization. Especially, the economic integration in the Far East has been implemented more quickly because of the boom of the Chinese economy.

Figure 1. Change of trading share per major region in the world

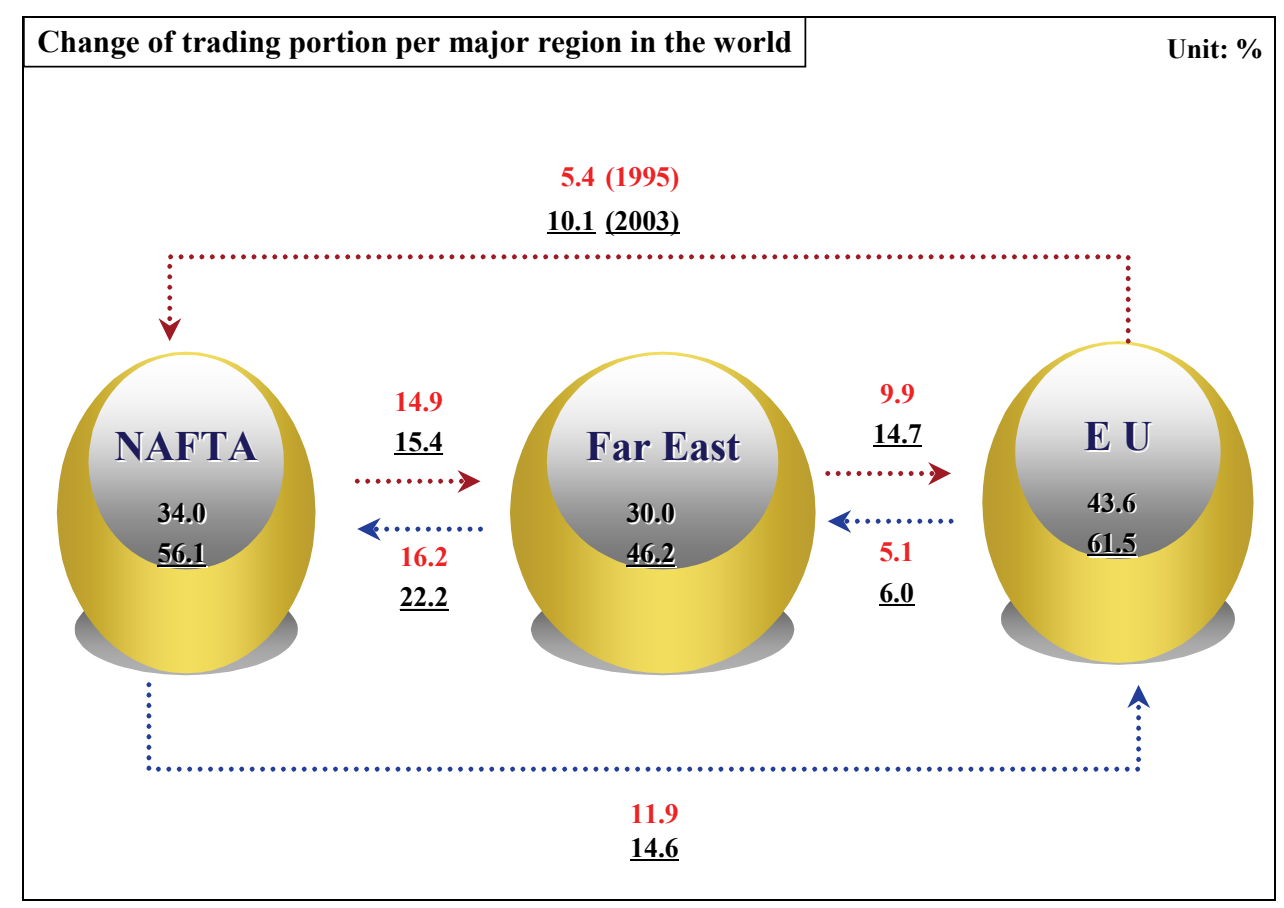

Note: Korea, China, Japan + ASEAN in terms of export.

Sources: WTO, International Trade Statistics 2004; IMF, Direction of Trade Statistics Yearbook 2004, 4.

Due to such changes of the trading environment between the three countries, central governments in Northeast Asia are recognizing the importance of cooperative logistics policy in improving their national competitive advantage (Rimmer, 2004). In spite of historical and political conflict among the three countries, these governments are seeking to capitalize on the economy-wide benefits to be derived from a world class logistics industry through cooperation among the three countries.

Under these circumstances, China, Korea and Japan are now participating in topdown regional organizations with strong transport and communications components, such as the Asia Pacific Economic Council (APEC) and make up the three countries in ASEAN Plus 3 (Rimmer, 2004). Significantly, there are also more informal intergovernmental arrangements typified by regular meetings between logistics entities, 
like port and airport, administrators in China, Korea and Japan in order to overcome some obstacles, such as Chinese disclosed policy and discordance of logistics system between the three countries.

\section{THE IMPACT ON PORTS AND LOGISTICS FLOWS}

The above changes have greatly affected the seaport industry in Asia (Han and Song, 2005) and major Asian ports play an important role in these processes. This has resulted in more concentrated traffic flows and growing intra-Asia port competition, notably in East-Asia. Under these circumstances, Chinese ports, like Shanghai, Ningbo, Qingdao and Tianjin, as well as Busan in Korea have changed their role following a logistics restructuring. For the purpose of achieving value-added logistics, Shanghai and Busan are developing huge distriparks like Luchao distripark near Yangshan deepsea port and North distripark near Busan new port for handling transhipment cargoes. In fact, these governments intend to take over the economic benefits being derived from a world class logistics industry.

In addition, the distribution pattern of maritime container flows is affected by this change. Kaoshiung in Taiwan, together with Busan in Korea played an important role in transhipment traffic until a few years ago. However, Shanghai recently become a hub port instead of Kaoshiung, and Tianjin and Qingdao have also changed their role from local to hub port, as shown in Table 3. Kaoshiung's container throughput decreased from 9.7 million TEU in 2004 to 9.4 million TEU in 2005. In this context, the Korean government strongly implemented its policy for maintaining a leading position in transhipment traffic, as Busan does not want to experience a decline in hub position like Japanese and Taiwanese ports. 
Table 3. The world rank of container cargo throughput in Far East (unit: '000 TEUs)

\begin{tabular}{c|c|c|c|c|c}
\hline Ports & 1995 & 2000 & 2002 & 2004 & 2005 \\
\hline \hline Singapore & $10,800(2)$ & $17,090(2)$ & $16,940(2)$ & $21,329(2)$ & $23,200(1)$ \\
Hong Kong & $12,550(1)$ & $18,100(1)$ & $19,144(1)$ & $21,984(1)$ & $22,420(2)$ \\
Shanghai & $1,527(19)$ & $\mathbf{5 , 6 1 3 ( 6 )}$ & $8,610(4)$ & $14,567(3)$ & $\mathbf{1 8 , 0 9 0 ( 3 )}$ \\
Shenzhen & $284(94)$ & $\mathbf{3 , 9 5 9 ( 1 1 )}$ & $7,610(6)$ & $13,625(4)$ & $\mathbf{1 6 , 0 9 0 ( 4 )}$ \\
Busan & $4,503(3)$ & $7,540(3)$ & $9,453(3)$ & $11,442(5)$ & $11,844(5)$ \\
Kaoshiung & $5,232(3)$ & $7,426(4)$ & $8,493(5)$ & $\mathbf{9 , 7 1 0 ( 6 )}$ & $\mathbf{9 , 4 7 1 ( 6 )}$ \\
Qingdao & $600(52)$ & $\mathbf{2 , 1 2 0}(\mathbf{2 5})$ & $3,410(15)$ & $5,140(14)$ & $\mathbf{6 , 2 6 8 ( 1 3 )}$ \\
Tianjin & $702(43)$ & $\mathbf{1 , 7 0 8 ( 3 1 )}$ & $2,410(24)$ & $3,814(18)$ & $\mathbf{4 , 8 1 7 ( 1 7 )}$ \\
\hline
\end{tabular}

Note: ( ) is the world ranking

Sources: derived from Containerisation International Yearbook (various years); Korea Maritime Institute (2006).

These changes of the port environment in the Far East have also strongly affected distribution patterns relying on trading and manufacturing. Before 2000 China had depended on Korea and Japan for importing half-finished products and raw goods like steel, semi-conducts and chemical goods and exported finished goods around the world (Drewry, 2003). Later on, China's manufacturing industry has quickly changed, following the dramatic economic growth labelling China as the 'world factory'. Major manufacturers investing in mobile, automobile, machinery and high-tech industries, previously located in Korea and Japan, have now launched into China. Evidently, the change of manufacturing location has influenced trading patterns and volumes among the three countries.

In this respect, the distribution patterns within this area have been made to rely on Chinese ports, especially Shanghai, Ningbo, Qingdao and Tianjin, and their logistics markets. The three countries are focused on planning Pan-Yellow Sea and Pan-East Sea as logistic platforms (Rimmer, 2004). In addition, many shipping companies have launched new services in order to receive a lot of cargo in the Pan-Yellow Sea. Many shipping routes intend to go via the Shanghai-Ningbo complex and the ports of North China.

These emergences changing East-Asian logistic networks, are shown in Figure 2. In the early-90s, liners were directed to North America via Taiwan, Busan and Japanese ports. Between mid-90s and 2003, the trend has changed and the shipping routes moved from Taiwan to Central China, calling on ports like Shanghai. Therefore, carriers gradually skipped Taiwan and Japanese ports as they were strongly launched into Central and North Chinese ports. The current shipping routes confirm that the 
main liners are now directed to North America and Europe by way of Shanghai, Qingdao and other North Chinese ports. More recently, Busan as well seems to face the same challenges as Taiwan and Japan, suffering the competition of emerging Chinese ports.

Figure 2. The trend of shipping routes in Far East

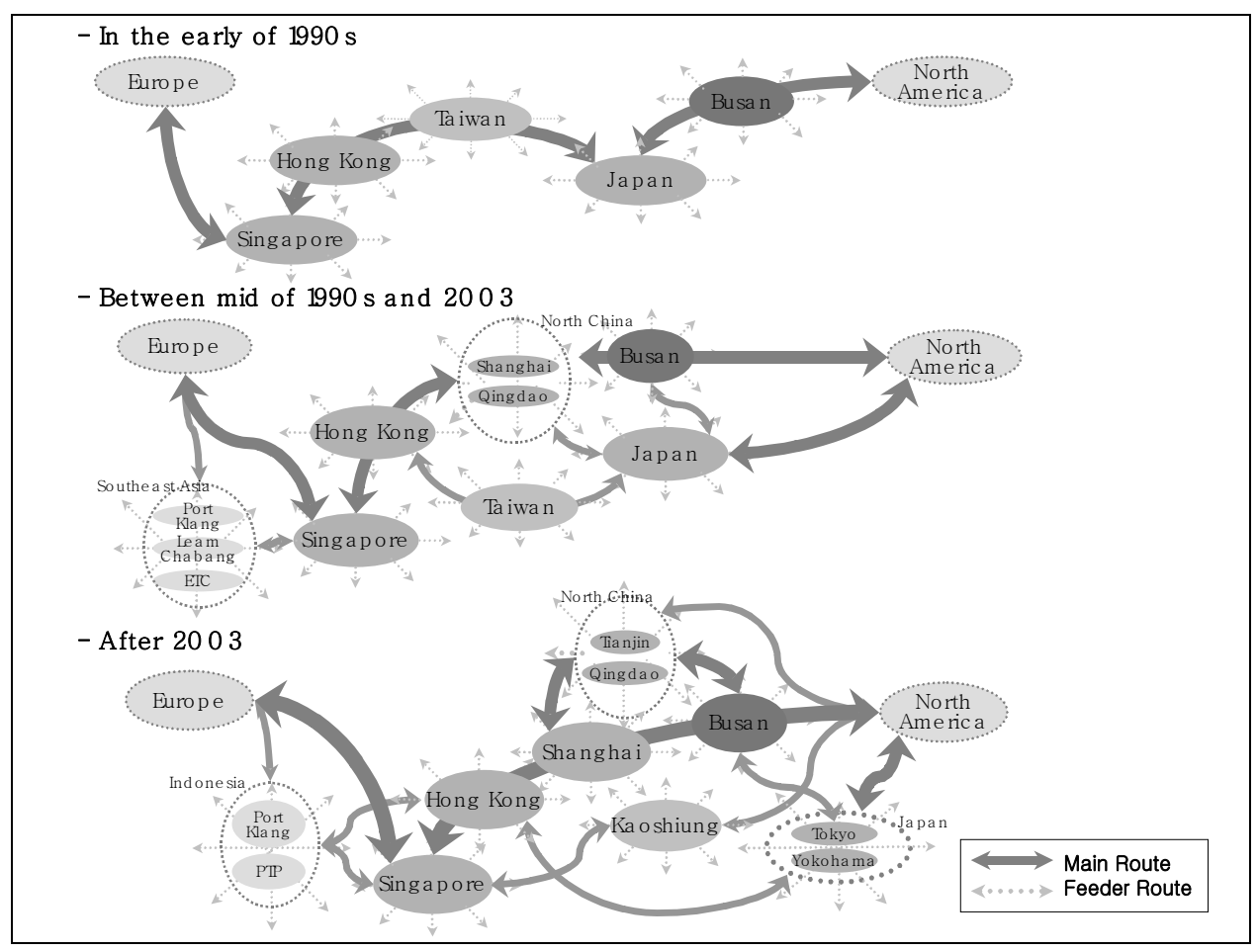

Source: authors modified from Ministry of Maritime Affairs and Fisheries (2005)

The above changes have resulted in fierce competition between shippers and ports, based on global vertical specialization of industry in low-cost clusters like China (Ernst, 2002). They are recognizing the importance of connections between shipping and inland logistics to cope with customers' needs and for obtaining additional cargo. 


\section{SHIPPING LINES: PATHS OF OVERSEAS EXPANSION IN THE EAST-ASIAN LOGISTICS MARKET}

The former political and economic fragmentation in the Far East had a deep impact on the past commercial relationships between countries. However, the current trend, progressively removing trade barriers and tariffs among East-Asian nations, is now calling for a more concentrated management of cargo flow, as well as electing some key hub ports and logistics platforms as gateways for different regions. In the light of these transformations, shipping lines need to revise their country-based approach in logistics, widening their geographical scope and, more importantly, enhancing operational and strategic coordination across political borders.

The dramatic changes occurring over the last ten years which induced shipping lines to enter the logistics business did not spare East-Asia as the market showing the highest traffic growth in the world. In fact, the above factors represented a strong driver for incoming foreign investors such as manufacturers, shipping lines, terminal operators, logistics companies, etc. Nevertheless, foreign players still have to face some political and cultural entry barriers in many East-Asian countries (i.e. former Chinese legislation on Sino-foreign JVs, etc.), limiting overseas direct investments especially in the 'port domain'. More recently, these nations are undertaking processes of reform, leading to the progressive erosion of such environmental obstacles.

As mentioned earlier, over the last few years, many carriers were called to widen their vision, both investing abroad (internationalization) and entering new businesses along the transport chain (vertical integration). Anyway, generally speaking, major shipping lines revealed a deeply different involvement in logistics operations in terms of turnover, geographical spread, and range of supplied services.

The Far East logistics market clearly shows the predominant position of Asian players. Among major Western carriers only Maersk has a wide and well established presence in this logistics market. The other big European shipping lines such as MSC, CMA-CGM and Hapag-Lloyd, although including this region in their maritime network as well as offering intermodal solutions (often resorting to third-party providers), they still do not supply integrated logistics services. Maersk Line, essentially after the takeover on Sealand, looks at the Far East, and predominantly at the P.R of China, as a key market for its process of vertical integration in Asia. Anyway, besides this powerful 'outsider', all the major Asian shipping lines, except Evergreen and China Shipping, still are the leading actors of the East-Asian logistics 
market.

This survey, regarding a sample of carriers operating in the East-Asian market, aims at analysing spatial and temporal aspects of the firm's internationalisation process as well as the wideness of its vertical integration (see Table 4), in order to highlight the impact of entry barriers (Stigler, 1968; Carlton and Perloff, 1994: p.110) in such process of firm's expansion.

\subsection{Driving overseas expansion: the 'home market' factor}

A cross-analysis of the biggest Asian players reveals some common features that somehow refer to the peculiarity of Asian business models, developing in a context which is deeply influenced by social and political factors.

In fact the firm remains to a great extent 'spatially embedded' in the sense that while companies may become 'international' in scale they display features proper to their local/domestic origins (Granovetter, 1985: 481; Olivier et al., 2005). In such respect, it is worth mentioning the organisational implications of spatial embeddedness of firms, mainly in terms of corporate governance paradigms. As argued by Dicken et al. (1994: 40), for a majority of global firms "high level functions remain strongly concentrated geographically, primarily in the firms' home country or region precisely because they are so deeply embedded locally". The behaviour of shipping lines which are willing to concentrate the power in a home-based business-unit, confirms this general assumption.

The analysis of the East-Asian logistics market shows that the home country is often the environment from which carriers found their process of vertical integration. Only after having acquired the necessary know-how, they undertake a path of internationalization and 'export' their knowledge overseas. Exactly here the concept of embeddedness reveals its root as through such a sequence TNCs are likely to carry signs of national identity as they globalise (Olivier et al., 2005).

In many cases the evolution of competition in the domestic market represents an important factor for the choice of vertical integration and often acts as a 'push factor' leading to international expansion. In particular the three big keiretsu, NYK, MOL and $\mathrm{K}$-Line, have been in the logistics sector since the late-1980s when in Japan pioneering logistics centres were born. For these carriers the home country $(20 \%$ of warehouses as average) and, more in general in Asia (45\% for NYK, even $75 \%$ for K-line), still represent the dominant markets of expansion. Similarly, Korean chaebol (Hanjin and Hyundai) as well, began their integration process in the domestic arena, currently their 
most relevant business. Fairly peculiar is the case of the Hanjin group, where there is a clear-cut separation between domestic activities and overseas operations. Hanjin Transportation, sister company of Hanjin Shipping deals with logistics in Korea while Hanjin Logistics (born in the US and under the direct control of the carrier's management), is focused on the overseas business (Asia and USA). Also for OOCL and Cosco the domestic market (Hong Kong-SAR and China mainland respectively) represent an important push factor in triggering vertical integration and international expansion.

Different is the case of NOL as the entry in logistics has been determined through the big takeover of APL in 1997. The wide network inherited in the US represents a strong competitive advantage in the North American context. As easily understood, the role of the home market is fairly marginal, despite the importance of Singapore in its regional context. For the Maersk Line as well its own domestic market, located in a small European country, does not represent a real push factor for expansion, although the Maersk Group acts for a substantial portion of the Danish GDP. Therefore, the NOL and Maersk stories, although rather different, have some further aspects in common as we will see later (see 5.4).

\subsection{Moving early-steps in foreign growth: the 'psychic distance' concept}

In analysing the path of internationalisation in the logistics industry, the implementation of the behavioural concept of 'psychic distance' brings interesting insights (Johanson and Vahlne, 1977). This model suggests that firms are likely to engage in transnational activities closest to their domestic markets. The reason is that geographical proximity was assumed to imply cultural proximity. Managers are used to succeeding in those markets they are linguistically, psychologically and culturally familiar with (Olivier et al., 2005).

The empirical study of the spatial presence of carriers and the analysis of the timeframe of overseas investments seem to confirm it. In fact, the surrounding geographical areas constitute, in most cases, the markets where it is likely to begin the path of expansion: Hong Kong, Singapore, South-East Asian countries in general and, outside Asia, the US. The latter, thanks to the dramatic trade growth on the transpacific, is a key market where shipping lines can boast many years of experience. Both Japanese keiretsu, early-movers in the logistic industry, and the chaebol adopted similar paths of internationalization towards those areas although following different timeframes. 
The mainland of China, previously close to foreign participation in domestic business, experienced in the 1990s a deep process of institutional reform, leading to the progressive opening of its economic environment. As a result, China only in a second phase, late 1990s-early 2000s, due to the growing Foreign Direct Investments (FDI), hosted first incoming logistics branches of carriers' groups (i.e. NYK, MOL and APL).

The Hong Kong-based OOCL and the state-owned Cosco began their process of integration relatively late. OOCL, leading 'ethnic Chinese conglomerate', based its process of integration in logistics on the Chinese market, being able to exploit its privileged relationships with the Beijing Government. The state-owned Cosco, although entering logistics operations do not support yet its wide network in China with relevant overseas investments.

In the light of the arguments formerly brought in 5.1, Maersk and NOL represent an exception as they are not predominantly targeting the countries around their domestic markets. The Danish carrier shows a well-balanced portfolio ${ }^{3}$ both worldwide and within the Far East, while NOL is more focused on the US market (70\% of the warehousing capacity) following the takeover on APL. More recently, it invested in some East-Asian nations as well.

\subsection{Managing vertical integration: wideness of supplied services}

Spatial and temporal constructs in overseas logistics expansion, also bring implications related to the 'wideness of entry' (vertical integration) in this emerging business. The wideness of supplied services is not only the result of a planned corporate strategy but also derives from the push of the demand in domestic and leading overseas markets.

Early-movers in logistics like the Japanese carriers followed the evolving requests of shippers in the home country and in the US, establishing its own network of subsidiaries (predominantly Wholly Owned - WOS). In particular, NYK Logistics shows a turnover of around 2.5 USD billion (the double of MOL and K-Line together) is able to offer services ranging from cargo consolidation, to value-added services (VAS), and even to consultancy and supply chain management. Hanjin and Hyundai, after having developed a domestic organization in logistics, began offering logistics services overseas, building up a small network of subsidiaries. Anyway the range of services is fairly narrow and, they often have to outsource operations to third-party

\footnotetext{
${ }^{3}$ The geographical coverage (see also Table 4) is evaluated in terms of turnover as Maersk Logistics is not use to own and manage warehouses, contrary to NYK, MOL, APL, etc.
} 
providers.

OOCL and Cosco, in the light of their recent process of integration can only offer a relatively limited range of services, often resorting to outsourcing (third-party providers).

Finally, NOL (APL) and Maersk Line, although mainly thanks to their respective takeovers, are now able to supply a wide range of services going to consultancy, supply chain management and visibility.

\subsection{Overcoming (port) entry barriers: M\&As and chaotic paths of entry}

Academic business literature has dealt with the issue of internationalization of Asian companies, emphasizing their huge growth in many industries. Li (2003) considers that Asian companies have developed exceptional capacities of 'leapfrogging' traditional steps of internationalization, in order to remain competitive in comparison to their Western rivals. This approach aims at creating a breakthrough with traditional positivist theories, which have identified typically evolutionary internationalization models. Warner et al. (2004) has brought similar arguments by stressing the success of Chinese companies, which have adopted non-linear internationalization paths, leading them to 'leapfrog' some steps of development, often resorting to M\&As.

Later on, Olivier et al. (2005) pointed out that in the port industry this atypical internationalization process has led the Asian latecomers - and in particular the Chinese transnational terminal operators - to dominate the industry in a few years. Empirical evidence in the port sector suggests to extend the analysis to the logistics market as this is one of the key phases of the value chain in which carriers aim to vertical integrate.

In fact due to the institutional and political framework in some Far Eastern countries, shipping lines have sometimes resorted to sui generis paths of integration and internationalization.

In P.R. of China and South-East Asian countries foreign operators had (and, partially, still have) to face relevant barriers to enter intermodal, warehousing \& distribution operations and especially container port handling (De Langen and Pallis, 2006), due to the institutional context still partially in force. Exactly the port system in the above countries, currently experiencing a process of reform and partial privatisation, proved to be adverse to the 'dedicated terminal' model as well as to foreign WOS. Therefore, the port industry shows the strongest barriers for carriers' vertical integration within the 'case study' area. 
Anyway such obstacles could not prevent shipping lines from overseas growth, as they undertook chaotic pathways of integration and aggressive financial transactions (M\&As).

In China now, only a handful of foreign terminal operators (i.e. carriers) have successfully entered the port industry. In particular, the shipping companies, not endowed with marine container facilities, have necessarily recurred to establish efficient logistics connections with the hinterland, securing inland container depots and warehouses. For example, in the mid-1990s Hanjin heavily invested in China's inland terminals and, in recent years, it has entered the logistics business as well without any dedicated port terminals. The same considerations might be referred to other carriers - such as OOCL, MOL, NYK, APL/NOL and Maersk Line - adopting "chaotic" entry pathways through investments in upstream activities, even in absence of available port space.

Besides China, also in other contexts such as Thailand, Cambodia, Malaysia and Indonesia, although to a lower extent, carriers like K-Line and NYK (see Figure 3) leapfrogged marine terminals entry.

Those trends are seldom coupled with aggressive financial strategies in order to acquire the whole network of local or even international players. In such a way carriers may rapidly expand their geographical coverage and also enter into emerging markets. In such respect, NOL and Maersk Line represent the most evident cases. The former, through the takeover on APL (1997), widened its maritime network (very important for the US market) as well as acquired the large port, intermodal and logistics network of the US carrier. In such a way NOL rapidly carried out a wide-scale vertical integration. Likewise the acquisitions of Sealand and P\&O Nedlloyd rapidly enlarged Maersk's port network and cast the Danish carrier into the logistics business.

Moreover, the above environmental factors have also induced carriers to stipulate cooperative agreements with local players (i.e. with Sinotrans in China), namely jointventures or simple outsourcing agreements, in order to accede to intermodal and logistics services.

\section{DISCUSSION}

East-Asia is now experiencing a two-fold trend. On the one side, the progressive economic integration and the dramatic growth of merchandise trade are driving carriers to heavily invest in logistics. On the other side, shipping lines still have to face 
institutional and political barriers to entry. Although these environmental obstacles are progressively falling over time, they still represent a deterrent for foreign newcomers. In particular, seaport entry barriers revealed to be the most critical stage of the transport chain. Nevertheless, as previously shown, the unfaltering will of leading shipping lines of achieving successful vertical and horizontal expansions, often led them to overcome (or avoid) such environmental obstacles.

In this respect, the empirical analysis of spatial and temporal constructs of carriers' investments across East-Asian countries, have revealed some sui-generis pathways of expansion (i.e. 'leapfrogging') willing to skip such barriers.

The empirical investigation carried out on the East-Asian logistics context clearly proved the adoption of two diverse leapfrogging strategies:

1.1. The former concerns the linearity of firm's vertical integration's process. If during the logical sequence of integration firms meet with strong barriers to entry or they have not enough skills and technical competencies to enter a market, they may decide to leapfrog that phase, directly investing in the following stage of the chain (i.e. 'chaotic pathway');

z.2. The latter is referable to financial operations aiming at acquiring shares in another company and, sometimes, to take control over it. Hence it is possible to penetrate quite rapidly in new markets, which usually present high barriers to entry.

Furthermore, the relevance of chaotic pathways (case sub 1) achieved by leading players raises the problem of the carriers' vertical integration consistency across various logistical layers. In particular, the match of NYK's maritime, port and distribution networks worldwide (see Figure 3) clearly reveals the inadequacy of the port network in China and Southeast Asia. Moreover, it also raises the issue of the unbalanced growth among the different layers of the NYK's transport chain in other areas such as Northern Europe, Med rim and South America, where the port capacity is often insufficient. The lack of 'fit' between the different logistical layers is clear evidence witnessing the importance of seaports entry barriers and their 'distortion effect' on carriers' expansion strategies. 


\section{CONCLUSIONS}

The notion of 'leapfrogging' applied to carriers' logistics branches in the East-Asian context, emphasized the role of entry barriers in seaports. Institutional and legal frameworks at state, regional and municipal level as well as port authority governances led ports to take a crucial position within the logistics chain. The relevance of current institutional and cultural entry barriers for incoming firms, despite recent opening policies, suggests a deeper investigation on the relationships/conflicts between overseas companies and host institutions. Therefore, the analysis of entry barriers in ports deserves more attention in future studies. In particular, the potentially discriminatory behaviour of port authorities in the light of carriers' nationality may easily drive to asymmetrical market conditions and to a distortion of firms' expansion pathways.

Moreover, the empirical evidences coming out from the East-Asian context raise some stimulating questions for future studies and researches.

Are those non-linear paths of integration an Asian peculiarity, or is it possible to find out similar experiences in other markets showing such entry barriers (i.e. institutional, political, port authority governance, etc.)? The results of the NYK case suggest extending the analysis to other contexts, such as Europe and North America.

The previous sections have pointed out how Asian players frequently resorted to non- linear (chaotic) paths of entry. Are those strategies typical of Asian firms or do they represent a successful behaviour of leading players, independently by their nationality and cultural identity?

The recent success of carriers like MSC and CMA-CGM - even if limited to the liner shipping industry - needs a deeper consideration and lays down some interesting questions about their possible future paths of vertical integration. Their recent entry processes in the stevedoring business may bring some suggestions for interpreting eventual forthcoming steps in logistics operations. 


\section{REFERENCES}

Carbone, V., Gouvernal, E., 2005, "Supply Chain and Supply Chain Management: Appropriate Concepts for Maritime Studies?," International Workshop on New Generation Port Cities and Their Role in Global Supply Chains, The University of Hong Kong, December, 12-14.

Cariou, P., 2001, "Vertical Integration within the Logistic Chain: Does Regulation Play Rational? The Case for Dedicated Container Terminals," Trasporti Europei, 7(17), 37-41.

Carlton, D. Perloff, J., 1994, Modern Industrial Organization, New York, HarperCollins College Publishers.

Containerisation International Yearbook (various years), Informa UK Ltd., London.

De Langen, P. and Pallis, A., 2006, "Analysis of Entry Barriers in Seaports," Proceedings (CD-Rom) of the IAME Conference, Melbourne, July 12-14.

De Souza Junior, G.A., Beresford, A. and Pettit, S.J., 2003, "Liner Shipping Companies and Terminal Operators: Internationalisation or Globalisation?," Maritime Economics \& Logistics, 5, 393-412.

Dicken, P., Forsgren, M. and Malmberg, A., 1994, "The local embeddedness of transnational corporations," and in Globalization, Institutions, and Regional Development in Europe, Amin, A. and Thrift, N., Oxford, Oxford University Press.

Drewry Shipping Consultants, 2003, China's Transport Infrastructure and Logistics, London.

Drewry Shipping Consultants, 2004, Annual Review of Global Container Terminal Operators, London.

Ernst, D., 2002, "Global Production Networks and the Changing Geography of Innovation Systems: Implications for Developing Countries", Economics of Innovation and New Technology, 497-523.

Ferrari, C. and Benacchio, M., 2000, "Market Structure in Container Terminal Operators and Port Services," a paper presented at the IAME Conference, 1315 September, Naples.

Frémont, A. and Soppé, M., 2003, "Les Stratégies des Armateurs de Lignes Régulières en Matière de Dessertes Maritime," Proceeding of Maritime Transport, 
Globalisation, Regional Integration and Territorial Development, June 3-5, Le Havre.

Granovetter, M., 1985, "Economic Action and Social Structure: The Problem of Embeddedness," American Journal of Sociology, 91(3), 481-510.

Han, J-K and Song, D-W., 2005, "Regional Network of Container Movements in Northeast Asia: Past, Present and Future, "Proceedings (CD-Rom) of the IAME Conference, June, Cyprus.

Haralambides, H., Cariou, P. and Benacchio, M., 2002, "Costs, Benefits and Pricing of Dedicated Terminals," International Journal of Maritime Economics, 4(1), 2134.

Heaver, T., 1994, "Restructuring Carriers to Logistics Suppliers: The Challenge for International Liner Shipping," Canadian Transportation Research Forum, May, Victoria Canada.

Heaver, T., 1996, "The Opportunities and Challenges for Shipping Lines in International logistics," paper presented at the 1st World Logistics Conference, Ramada Hotel, London Heathrow, UK.

Heaver, T., 2002, "The Evolving Roles of Shipping Lines in International Logistics," International Journal of Maritime Economics, 4(3), 210-230.

IMF, 2004, Direction of Trade Statistics Yearbook, No. 4

Johanson, J. and Vahlne, J-E., 1977, “The Internationalization Process of the Firm - a Model of Knowledge development and Increasing Foreign Market Commitments," Journal of International Business Studies, 8(1), 23-32.

Korea Maritime Institute, Shipping Statistics 2005.

Lee, S-W., 2005, Interaction between City and Port in Asian Hub Port Cities, Unpublished doctoral thesis, Seoul National University.

Li, P.P., 2003, "Toward a Geocentric Theory of Multinational Evolution: the Implications from Asian MNEs as Latecomers," Asia Pacific Journal of Management, 217-242.

McCalla, R.J., Slack, B. and Comtois, C., 2004, "Dealing with Globalisation at the Regional and Local level: the Case of Contemporary Containerisation," The Canadian Geographer, 48(4), 473-487.

Midoro, R., Musso, E. and Parola, F., 2005, "Maritime Liner Shipping and Stevedoring Industry: Market Structure and Strategies for Competition," 
Maritime Policy \& Management, 32(2), 89-106.

Ministry of Maritime Affairs and Fisheries, 2005, Development Plan of Feeder Network intra North East Asia, Government print, Republic of Korea.

Notteboom, T., 2004, "Container Shipping and Ports: an Overview,: Review of Network Economics, 3(2), 86-106.

Notteboom, T. and Winkelmans, W., 2001, "Structural Changes in Logistics: How Will Port Authorities Face the Challenge?," Maritime Policy \& Management, 28(1), 71-89.

Olivier, D., 2005, "Private Entry and Emerging Partnerships in Container Terminal Operations: Evidence from Asia," Maritime Economics \& Logistics, 7(2), 87115.

Olivier, D., Parola, F., Slack, B. and Wang J., 2005, "The Time Scale of Internationalisation: the Case of the Container Terminal Industry," International Workshop on New Generation Port Cities \& Their Role in Global Supply Chains, The University of Hong Kong, December 12-14.

Panayides, P.M. and Cullinane, K., 2002, “Competitive Advantage in Liner Shipping: a Review and Research Agenda," International Journal of Maritime Economics, 4(3), 189-209.

Panayides, P.M. and So, M., 2005, “The Impact of Integrated Logistics Relationships on Third-party Logistics Services Quality and Performances," Maritime Economics \& Logistics 7(1), 36-55.

Peters, H.J.F., 2001, "Developments in Global Seatrade and Container Shipping Markets: Their Effects on the Port Industry and Private Sector Involvement," International Journal of Maritime Economics, 3, 3-26.

Rimmer, P.J., 2004, "Global Flows, Local Hubs, Platforms, Corridors and Regional Economic Integration in Northeast Asia,” Journal of International Logistics and Trade, 1(2), 1-18.

Robinson, R., 2002, "Ports as Elements in Value-driven Chain Systems: The New Paradigm," Maritime Policy \& Management, 29(3), 241-255.

Robinson, R., 2006, "Port-oriented Landside Logistics in Australian Ports: a Strategic Framework," Maritime Economics \& Logistics, 8(1), 40-59.

Slack, B. and Frémont, A., 2005, “The Transformation of Port Terminal Operationsfrom the Local to the Global," Transport Reviews, 25(1), 117-130. 
Slack, B., Comtois, C. and Sletmo, G., 1996, "Shipping Llines Agents of Change in the Port Industry," Maritime Policy \& Management, 23(3), 289-300.

Stigler, G.J., 1968, The Organisation of Industry. Chicago, University of Chicago Press.

Warner, M., Hong, N-S. and Xiaojun, X., 2004, “'Late Development' Experience and the Evolution of Transnational Firms in the People's Republic of China," Asia Pacific Business Review, 10, 324-345.

WTO, 2005, International Trade Statistics, WTO publications, Geneva. 


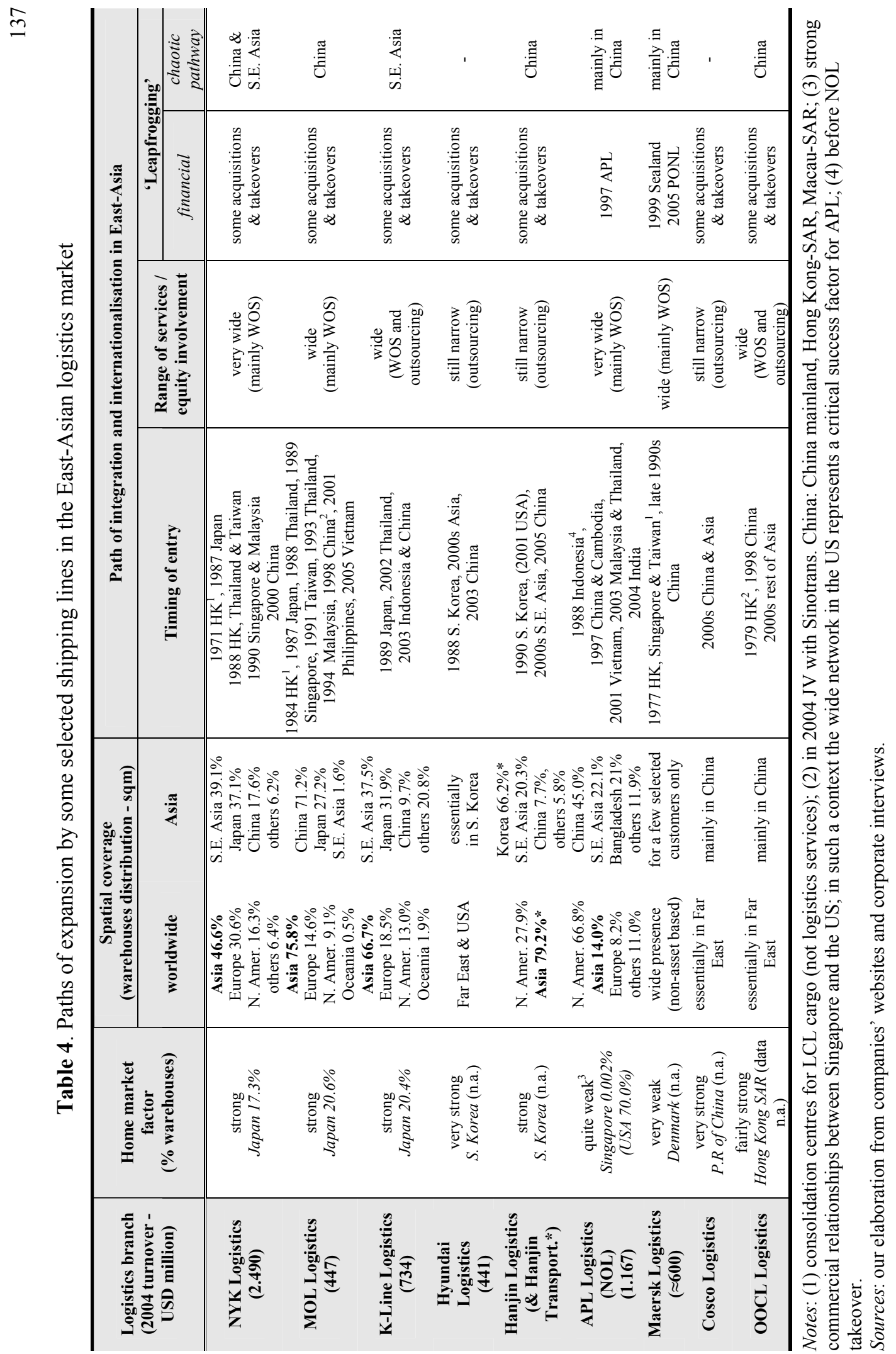




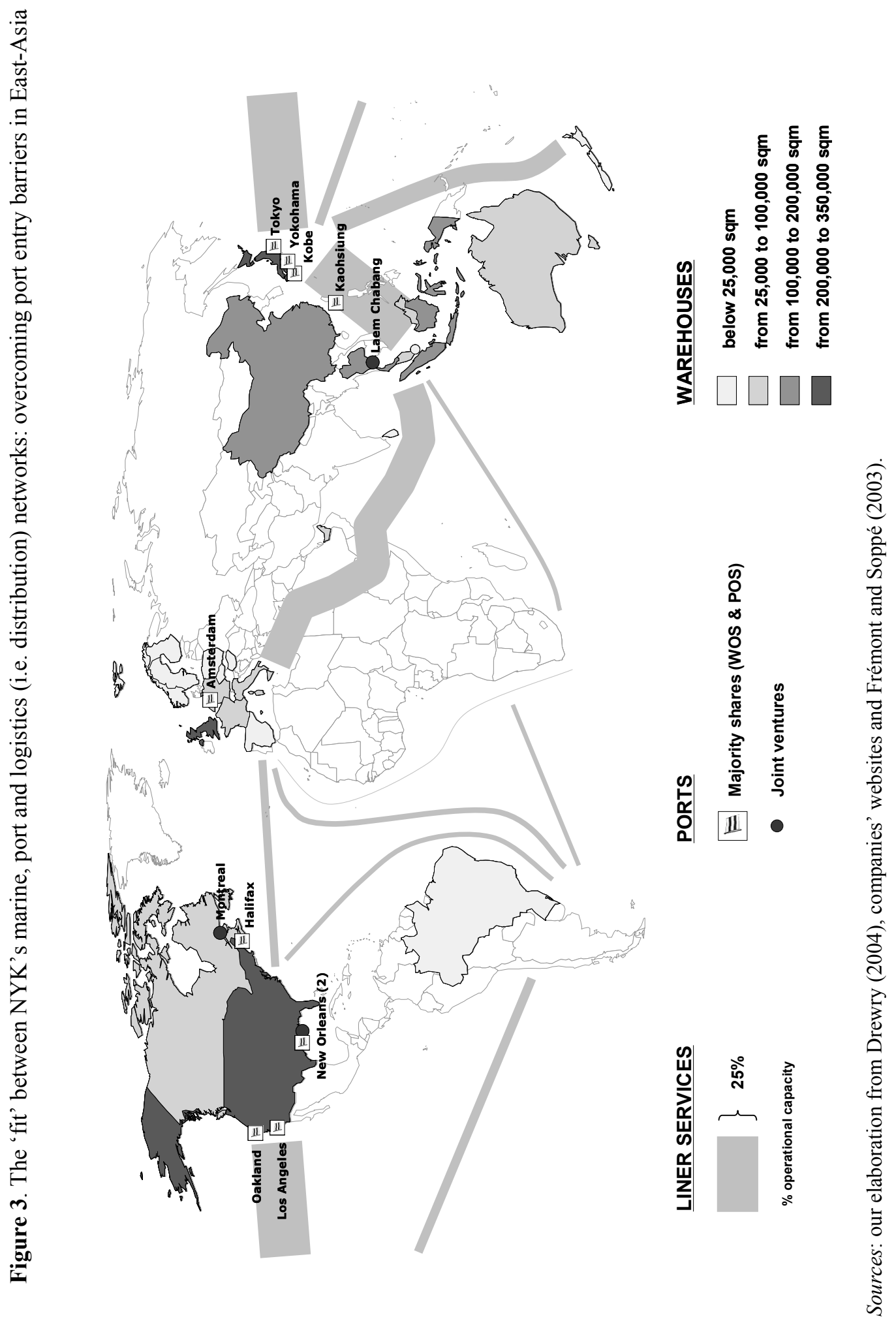

